\title{
Academic Entrepreneurship Education: Does Gender Matter?
}

\author{
Xenia Justus ${ }^{1, *}$ \\ ${ }^{1}$ Ostbayerische Technische Hochschule Regensburg, Human Resources Department, Department of Personnel Development, \\ Prüfeninger Str. 58, 93049 Regensburg, Germany
}

\begin{abstract}
Academic entrepreneurship education aims to train and raise awareness amongst students about entrepreneurial activity, thereby increasing the number of academic start-ups and spin-offs. However, as yet, there are very few findings on the gender-specific differences amongst potential entrepreneurs. Building on the current state of research, gender-specific differences in the form of various different components of entrepreneurial competence are examined. This study focuses in particular on (1) entrepreneurial knowledge, (2) domain-specific interest in entrepreneurship, (3) interest in leadership roles, and (4) entrepreneurial and (5) intrapreneurial intention. Based on an online survey of 281 students of a German and Czech university, the mean differences show that there are statistically significant lower values for female students than for male students for all the variables investigated, that is with exception to intrapreneurial intention. These findings underline the need for targeted promotion of female entrepreneurship within the context of academic entrepreneurship education.
\end{abstract}

Keywords: female entrepreneurship; entrepreneurship education; gender research; entrepreneurial competence; interest in entrepreneurship; leadership role

\section{Introduction}

"The incidence of female entrepreneurs is lower than that of male entrepreneurs in almost every country in the world" [1, p. 261]. Germany is no exception: here, the majority of companies are founded by men [2]. In 2017, the proportion of women in various start-up activities in Germany was 37\% [3].

Although an entrepreneur is often associated with the founding of a company, there is more to entrepreneurship than just this. Bechter et al [4] emphasise that an entrepreneur is constantly on the lookout for new opportunities and does not shy away from taking risks. Entrepreneurs also seek to implement innovations in a marketable way and make them available $[4,5]$.

In the last few years, female entrepreneurship has attracted more attention as a field of research. In current research discussions, several reasons have been put forward as to why the field of entrepreneurship is dominated by men [2, 6, 7, $8,9]$. However, the findings concerning this complex issue are not particularly conclusive. Within this context, Bechter et al [4] refer to gender-specific socialisation, gender-role stereotypes, negative self-perception, financial framework conditions and the very patriarchal structures that still frequently exist in society [10]. "In addition, fewer role models are available to female than male entrepreneurs" [9, p. 3]. Since role models are of particular relevance for entrepreneurship, an excessively male-dominated entrepreneurial image could have a negative influence on the entrepreneurial propensity of women [2].

Until now, research into the gender-specific differences amongst potential graduate entrepreneurs has received little attention. The focus of empirical studies often lies in the differences in the case of fully established start-ups, whereby gender is merely a control variable $[11,12]$. However, the empirically proven gender gap has prompted a growing number of researchers into start-up entrepreneurship to subject their models to gender-specific tests [12], since female-specific behaviour is overlooked in most theories [13]. "Concepts in entrepreneurship theory and practice have long been either dominated by a supposedly gender-neutral perspective, or mainly eulogized as part of a dominant male discourse lacking the complexity of theories on gender aspects" [6, p. 4]. In doing so, motivational components of entrepreneurial competence, for example domain-specific interest in entrepreneurship, interest in leadership roles and entrepreneurial intention, but also cognitive aspects, such as entrepreneurial knowledge, which can be positively influenced in the context of academic entrepreneurship education, are frequently neglected [14]. Here, competence can be understood as all cognitive skills and capacity to solve certain problems, as well as the associated motivational, volitional and social preparedness and skills to be able to use the solutions successfully and responsibly in various situations [15].

\footnotetext{
* Corresponding author: xenia.justus@oth-regensburg.de
} 
This paper attempts to close some of these research gaps. This study on gender-specific differences in academic entrepreneurship concentrates on the gender of the students as an independent variable and (1) entrepreneurial knowledge, (2) domain-specific interest in entrepreneurship, (3) interest in leadership roles, (4) entrepreneurial and (5) intrapreneurial intention as dependent variables.

\subsection{Entrepreneurial knowledge}

In cognitive psychology, a distinction is made between declarative and procedural knowledge [16, 17]. Declarative knowledge denotes static knowledge of domain-specific facts and concepts [18], for example knowledge of the financing options for technology-based start-ups. Procedural knowledge is understood to be practical knowledge [18], for example the development of business ideas. In this, the knowledge is not taught directly but rather is constructed individually by the students [17]. In academic entrepreneurship education, both declarative and procedural knowledge about entrepreneurship, business management, innovation, business planning and control is taught. Without entrepreneurial knowledge it would hardly be possible to establish a company, even if all other motivational conditions were fulfilled, since the rational problem solving cannot take place without the specialist knowledge this requires [19]. In this study, entrepreneurial knowledge was operationalised through knowledge about founding a company, active project management, staff management and motivation, innovation management, general economic understanding, creativity techniques and networks [20].

\subsection{Domain-specific interest in entrepreneurship}

Current approaches in interest research understand interest to be a specific relationship between a person and an object [21]. The interest in an object, a situation, an action or content normally forms gradually over previous experiences and has a certain stability [22]. In order to support the development of new interest in a certain topic or area (e.g. entrepreneurship), there first has to be initial contact which arouses curiosity in the corresponding content: thus, an instable, situational interest arises. The stabilisation of this interest takes time and is highly dependent on external influences. Aided by internalisation and identification, the transition from situational to stable, individual interest then ultimately takes place [21]. Against this background, the interest in entrepreneurship can be seen as a significant condition for the successful commencement and implementation of action (here: the establishment of one's own company).

\subsection{Interest in leadership roles}

Leadership means proactively thinking ahead and acting, anticipating and precipitating changes, and discovering new opportunities [4, 23]. Both concepts, entrepreneurship and leadership, are held responsible these days, to the same extent in practice and in theory, for the long-term success of entrepreneurship. However, the relationship between entrepreneurship and leadership is often overlooked. Rather, the impression is given that, despite the coexistence of both in successful entrepreneurship, it is usually only one of the two that is responsible for the success of a company [24].

\subsection{Entrepreneurial and intrapreneurial intention}

Entrepreneurial intention relates to the subjectively evaluated likelihood of establishing one's own company. In metaanalyses, intentions account for up to $31 \%$ of the actual, self-reported behaviour [25,26]. With respect to gender-specific differences, the majority of studies thus far have pointed to a greater likelihood of founding a company amongst men [12]. This could be, for example, because an entrepreneurial scene dominated by men offers few reference points for women with which they can identify and seek access [12]. Furthermore, the results of an empirical investigation by Walter and Walter [26] showed that an application-oriented entrepreneurial education effects a deeper interest in entrepreneurship amongst male students than amongst female students. This difference may indicate that the educational offerings do not appeal to female students in their current form. Intrapreneurship can be differentiated quite clearly from entrepreneurship. Moriano et al [23] define intrapreneurship as “(..) entrepreneurial behaviour within an existing organization, (...) which is comprised of three key dimensions: risk taking, innovation and proactiveness" (p. 105). An intrapreneur is also proactive and develops innovative ideas for new projects; in contrast to an entrepreneur, however, they do not bear the full financial and social risk [27].

Building on the analysis of the theoretical basis and the actual state of research, the hypotheses of this empirical study are explained in detail below.

- Hypothesis 1a: There are statistically significant positive correlations between entrepreneurial knowledge, interest in entrepreneurship, interest in leadership roles and entrepreneurial intention.

- Hypothesis 1b: There are no statistically significant correlations between entrepreneurial and intrapreneurial intention.

- Hypothesis 2a: Female students evaluate their entrepreneurial knowledge as statistically significantly lower than male students. 
- Hypothesis 2b: Female students demonstrate statistically significantly lower expressions of domain-specific interest in entrepreneurship, interest in leadership roles and entrepreneurial intention.

- Hypothesis 2c: There are no statistically significant differences in intrapreneurial intention between female and male students.

In the following section, the hypotheses formulated here are examined statistically.

\section{Methodology}

The already existing data from the EU project "Entrepreneurial skills on the Czech/Bavarian labour market" (goal ETZ 2014-2020, INTERREG V) were used to examine the hypotheses formulated above. The data were collected within the context of a non-experimental, cross-functional field study. The web-based student survey is looked at in detail below.

\subsection{Description of the random sample}

As already mentioned, the data were collected within the framework of an EU project (see above) on the basis of an online questionnaire survey conducted during the summer semester 2019 at the Ostbayerische Technische Hochschule Regensburg (OTHR) and the Institute of Technology and Business in České Budějovice (VŠTE). In total, 281 students participated. At the time of the data acquisition, 59.8\% of the respondents were enrolled at OTHR and $40.2 \%$ at VŠTE $(N=281)$. Of the participating students, $65.0 \%$ were female and $35.0 \%$ male. Most of the respondents $(67.3 \%)$ were aged 18 to 24 years. $86.4 \%$ of those surveyed were enrolled in a Bachelor course and 93.5\% were studying business administration.

\subsection{Survey materials}

To identify the gender-specific difference, relevant personal characteristics were collected by means of an online questionnaire survey. In order to measure the subject-specific interests of students in entrepreneurship, an adapted and abbreviated questionnaire regarding the interest of study [22] was used (a seven point Likert scale from 1 "does not apply at all" to 7 "completely applies"). The scale consisting of three items takes into consideration personal value-oriented valences as well as the intrinsic character of interest $(\alpha=.78$; exemplary item: "It is very important to me that I can attend entrepreneurship classes"). In order to measure the interest in leadership roles, the leadership motivation scale by Nicholson and Arnolds [28] was used. The scale consists of five items measured on a seven point Likert scale for interest in assuming management responsibility ( $\alpha=.87$; exemplary item: "I want to lead employees"). The entrepreneurial and intrapreneurial intention was gauged with one question in each case (exemplary item for entrepreneurial intention: "I have already thought seriously about establishing my own company or taking one over"; exemplary item for intrapreneurial intention: "It is my professional goal to become an innovation-capable employee (intrapreneur)"; a seven point Likert scale). The entrepreneurial knowledge of students was operationalized by the use of a scale $(\alpha=.88)$ consisting of 10 items (exemplary item: "Please assess your previously acquired competencies in founding a business"; a seven point Likert scale). On this occasion, the corresponding scale of the Global University Entrepreneurial Spirit Students' Survey [20] was abbreviated and adapted.

\subsection{Analyses}

The statistics programme IBM SPSS 25 was used for the analyses. First of all, fundamental analyses of scales for the control of distributional assumptions, as well as for the verification of the reliability and validity thereof, were carried out. Subsequently, various descriptive and correlation analyses were performed and the assessment of the differences in mean value examined using the t-test.

\section{Results}

After the fundamental analysis of scales, the descriptive and correlation analyses were performed. The mean values, standard deviations and correlative findings are presented in Table 1. 
Table 1. Mean values, standard deviations and intercorrelations for the investigated components of entrepreneurial competence

\begin{tabular}{|l|r|r|r|r|r|r|}
\hline Variable & M (SD) & (1) & (2) & (3) & (4) & (5) \\
\hline (1) entrepreneurial knowledge & $4.60(0.92)$ & - & & & & \\
\hline (2) interest in entrepreneurship & $4.77(1.39)$ & $.25^{* *}$ & - & & & \\
\hline (3) interest in leadership roles & $5.33(1.07)$ & $.45^{* *}$ & $.21^{* *}$ & - & & \\
\hline (4) entrepreneurial intention & $4.13(2.23)$ & $.34^{* *}$ & $.40^{* *}$ & $.36^{* *}$ & - & \\
\hline (5) intrapreneurial intention & $3.97(1.78)$ & $.19^{* *}$ & $.20^{* *}$ & $.21^{* *}$ & $.13 \mathrm{~ns}$ & - \\
\hline
\end{tabular}

Source: Author.

$* \mathrm{p}<.05 ; * * \mathrm{p}<.01$

As Table 1 shows, the mean values for entrepreneurial knowledge, interest in entrepreneurship and interest in leadership roles lie significantly above the average rating. The mean values for entrepreneurial and intrapreneurial intention on the other hand lie only slightly above the average rating. The standard deviations of the ratings investigated are relatively homogenous for entrepreneurial knowledge, interest in entrepreneurship and interest in leadership roles and should therefore be described as marginal. In the case of entrepreneurial and intrapreneurial intention, the values of the standard deviations indicate a rather heterogeneous distribution of attributes. This first finding points to the students in the business studies course showing a marked interest in the field of entrepreneurship. As expected, average, statistically significant positive correlations could be determined for correlations between the variable examined $(\mathrm{r}=.19-.45, \mathrm{p}<.05)$. Furthermore, the conjecture that there is no statistically significant correlation between entrepreneurial and intrapreneurial intentions is confirmed. Both constructs can be clearly, empirically distinguished from one another $(r=.13, p>.05)$.

In order to examine the hypotheses and to identify the gender-specific difference in the expression of different components of entrepreneurial competence, the mean differences were subsequently examined using the t-test. The results are presented in Table 2.

Table 2. Mean values, standard deviations, sample size, t-values and effect size of the gender-specific group comparison

\begin{tabular}{|l|c|c|c|c|}
\hline Variable & $\begin{array}{c}\text { Female students } \\
\mathbf{M}(\mathbf{S D}, \mathbf{N})\end{array}$ & $\begin{array}{c}\text { Male students } \\
\mathbf{M}(\mathbf{S D}, \mathbf{N})\end{array}$ & t-values & d $_{\text {Cohen }}$ \\
\hline entrepreneurial knowledge & $4.52(0.92,163)$ & $4.78(0.90,79)$ & $\mathrm{t}_{(240)}=2.09, \mathrm{p}<.05$ & 0.29 \\
\hline interest in entrepreneurship & $4.58(1.40,150)$ & $5.13(1.31,75)$ & $\mathrm{t}_{(223)}=2.83, \mathrm{p}<.05$ & 0.40 \\
\hline interest in leadership roles & $5.12(1.00,149)$ & $5.77(1.08,75)$ & $\mathrm{t}_{(222)}=4.47, \mathrm{p}<.005$ & 0.63 \\
\hline entrepreneurial intention & $3.77(2.22,162)$ & $4.91(2.06,79)$ & $\mathrm{t}_{(239)}=3.85, \mathrm{p}<.005$ & 0.53 \\
\hline intrapreneurial intention & $3.98(1.80,162)$ & $3.95(1.77,79)$ & $\mathrm{t}_{(239)}=0.13, \mathrm{p}>.05$ & 0.02 \\
\hline
\end{tabular}

Source: Author.

The t-tests carried out for the independent samples showed statistically significant mean differences between female and male students for all the variables investigated. The male students consistently produced higher statistically significant mean values than their female counterparts. It was only in the expression of intrapreneurial intention that, as expected, no statistically significant differences between the two comparative groups could be determined. As a consequence, the hypotheses formulated above were confirmed.

\section{Discussion}

Table 1 illustrates that the students surveyed evaluate their entrepreneurial knowledge as better than average. In addition, the findings indicate that students have a marked interest in entrepreneurship as well as an interest in leadership roles. Since students generally select their course of study based on their interests, it is reasonable to assume that they would have particular interest in certain aspects of economic sciences. In their studies, they are also confronted with many different areas of economic sciences, e.g. with entrepreneurship, founding start-ups, and therefore have the opportunity to develop an interest, even if this was absent at the beginning. The values for entrepreneurial and intrapreneurial intentions also conform to the hypotheses. Some of the students surveyed have already given serious consideration to establishing their own companies, some have not considered this at all, which also confirms the heterogeneous standard deviation. These findings are in line with founding activities in general. Serious consideration had also not been given to intrapreneurship. This is probably something that would generally change with the first major internship or with the first job, since innovations are context related.

The correlative findings underline that persons with high values in interest in entrepreneurship also demonstrate greater entrepreneurial knowledge and interest in leadership. Particularly notable is the comparatively high positive 
correlation between interest in entrepreneurship and entrepreneurial intention, which also conforms to the hypotheses. Within the framework of the aforementioned EU project, it was investigated as to which factors contribute most strongly to the formation of entrepreneurial intention. In this, domain-specific interest in entrepreneurship $(\beta=.35, p<.001)$, interest in leadership roles $(\beta=.23, \mathrm{p}<.01)$ and entrepreneurial knowledge $(\beta=.21, \mathrm{p}<.01)$ were identified as statistically significant predictors. These variables go a long way to explain the variance for entrepreneurial intention $\left(\mathrm{R}^{2}=.35, \mathrm{~F}\right.$ $(1,124)=22.08, p<.001)$ [29]. The constructs entrepreneurial and intrapreneurial intention can be clearly differentiated from one another, both theoretically and empirically, which confirms the findings of this study. It is clear that not every person who thinks and acts innovatively has the intention of setting up their own business.

The findings of this study show that male students evaluate their own entrepreneurial knowledge as being much higher than do their female counterparts. Whether or not male students actually do have more comprehensive entrepreneurial knowledge than female students or simply have more confidence in themselves can only be verified with further validity criteria (e.g. comparison of examination grades). In addition, they display a significantly stronger domain-specific interest in entrepreneurship, interest in leadership roles and entrepreneurial intentions. Against the theoretical background discussed above and the findings of empirical studies, these results are plausible, confirm the hypotheses of this investigation and, furthermore, replicate actual founding activity in Europe. Within this context, female students may have lesser entrepreneurial self-efficacy and risk tolerance, and/or the current offerings in academic entrepreneurship education do not appeal to female students.

The following limitations should be noted for this study: (a) students from two universities were surveyed. The robustness of the data could be increased through the inclusion of further universities or colleges as well as of other faculties; (b) the validity of intention as a behavioural predictor has been proven thus far only in a general context and not in the context of establishing a business $[12,25]$. As a result, how many female and male students actually do realise their entrepreneurial plans cannot be quantified.

This paper has specific implications for the research and promotion of business establishment. Since the effect of entrepreneurship education would appear to be dependent on gender, the first step should be to verify whether or not the current promotional measures are sufficiently tailored to the needs of potential female entrepreneurs. The second step should be the development, testing and implementation of targeted offerings for female students. Further research into female entrepreneurship can contribute to the better conception of academic entrepreneurship education.

\section{Conclusion}

Although the proportion of women establishing businesses has increased across Europe in recent years, as has the number of women who see establishing a company as an alternative to a conventional career path [3], the still low level of female entrepreneurship raises the question of how these numbers can be raised. Against this background, the following recommendations can be derived for targeting women within the context of entrepreneurship education [4, 30, 31]:

- The offers already available should be adjusted for female entrepreneurs. New formats should be conceived, e.g. coaching for female students to illustrate the opportunities and risks of realising their own ideas, or women-towomen mentoring programmes.

- $\quad$ For the entrepreneurial motivation of female students, highlighting real role models can be of great importance. To this end, guest lectures by successful female entrepreneurs could be employed to a greater extent. By showing female students that successful female entrepreneurs are not superwomen, the entrepreneurial self-efficacy of the female students will also be bolstered.

However, in order to improve the theoretical and empirical basis as well as the quality and the effectiveness of the targeted measures, further empirical gender studies in the area of female entrepreneurship are needed [6]. In addition, the corresponding changes in family and economic policy, in the structure of the labour market, and in societal norms are essential [4].

\section{References}

1. K. Terrell, M. Troilo, Values and female entrepreneurship. International Journal of Gender and Entrepreneurship. 2(3), 260-286 (2010)

2. B. Schulte, Unternehmensnachfolgen und Entrepreneurship Education. Wiesbaden: Springer (2019)

3. G. Metzger, KfW Start-up Monitor 2018 [online]. Available at: https://www.kfw.de/PDF/DownloadCenter/Konzernthemen/ Research/PDF-Dokumente-Gründungsmonitor/Gründungsmonitor-englischeDateien/KfW-Start-Up-Monitor-2018_EN.pdf(2018)

4. M. Bechter, M. Raich, P. Schober, Auf dem Weg zur erfolgreichen Unternehmerin - Vom Entrepreneurship zum Leadership [On the way to becoming a successful entrepreneur - from entrepreneurship to leadership]. In M. Raich, 
H. Pechlaner, H. H. Hinterhuber, Entrepreneurial Leadership. Wiesbaden: Deutscher Univesitäts-Verlag, 131-144 (2007)

5. D. F. Kuratko, Entrepreneurship. Theory, process, practice. Boston: Cengage Learning (2017)

6. S. Birkner, K. Ettl, F. Welter, I. Ebbers, Women's Entrepreneurship in Europe: Research Facets and Educational Foci. In S. Birkner, K. Ettl, F. Welter, I. Ebbers, Women's Entrepreneurship in Europe. Cham: Springer Nature Switzerland, 3-14 (2018)

7. T. L. Michaelis, J. M. Pollack, P. Mulvey, Gender Bias and Venture Funding: Discussing Bias in the Entrepreneurship Classroom. Entrepreneurship Education and Pedagogy. 3(2), 154-181 (2019)

8. J. Wu, Y. Li, D. Zhang, Identifying women's entrepreneurial barriers and empowering female entrepreneurship worldwide: a fuzzy-set QCA approach. International Entrepreneurship and Management Journal. 15(3), 905-928 (2019)

9. C. S. Zerwas, Work-Life-Balance and Women's Entrepreneurship. An Exploration of Influencing Factors. Cham: Springer Nature Switzerland (2019)

10. L. Balachandra, T. Briggs, K. Eddleston, C. Brush, Don't Pitch Like a Girl!: How Gender Stereotypes Influence Investor Decisions. Entrepreneurship: Theory and Practice. 43(1), 116-137 (2019)

11. V. Iffländer, A. Sinell, M. Schraudner, Does Gender Make a Difference? Gender Differences in the Motivations and Strategies of Female and Male Academic Entrepreneurs. In S. Birkner, K. Ettl, F. Welter, I. Ebbers, Women's Entrepreneurship in Europe. Cham: Springer Nature Switzerland, 65-82 (2018)

12. S. G. Walter, Gründungsintention von Akademikern [Founding intention of academics]. Wiesbaden: Gabler (2008)

13. C. Henry, L. Foss, H. Ahl, Gender and entrepreneurship research: A review of methodological approaches. International Small Business Journal. 34(3), 217-241 (2016)

14. A. Tittel, O. Terzidis, Entrepreneurial competences revised: Developing a consolidated and categorized list of entrepreneurial competences. Entrepreneurship Education. 3, 1-35 (2020)

15. F. E. Weinert, A Concept of Competence: A Conceptual Clarification. In D. S. Rychen, L. H. Salganik, Defining and Selecting Key Competencies. Seattle: Hogrefe \& Huber Publishers, 45-65 (2001)

16. J. R. Anderson, Skill acquisition: compilation of weak-method problem solutions. Psychological Review. 94(2), 192-210 (1987)

17. A. Renkl, Wissenserwerb [Knowledge acquisition]. In: E. Wild, E., J. Möller, Pädagogische Psychologie. Berlin, Heidelberg: Springer, 3-26 (2009)

18. C. Brühwiler, L. Hollenstein, B. Affolter, H. Biedermann, F. Oser, Welches Wissen ist unterrichtsrelevant? Zeitschrift für Bildungsforschung. 7, 209-228 (2017)

19. Z. Caha, S. P. Sassmannshausen, J. F. Faltermeier X. Justus, Unternehmerische Kompetenzen an Hochschulen für angewandte Wissenschaften am Beispiel einer Hochschule in Ostbayern und Südböhmen [Entrepreneurial skills at universities of applied sciences using the example of a university in Eastern Bavaria and South Bohemia]. Lüdenscheid: RAM-Verlag (2017)

20. H. Bergmann, S. Golla, Unternehmertum an Hochschulen in Deutschland [Entrepreneurship at universities in Germany] [online]. St. Gallen/Fulda: Schweizerisches Institut für Klein- und Mittelunternehmen. Available at: http://www.guesssurvey.org/resources/nat_2016/GUESSS-Bericht-Deutschland-2016_30Sept2016.pdf (2016)

21. U. Schiefele A. Krapp, K.-P. Wild, A. Winteler, Der "Fragebogen zum Studieninteresse" (FSI) [The "Questionnaire on interest in studying"]. Diagnostica. 39(4), 335-351 (1993)

22. A. Krapp, T. Hascher, Theorien der Lern- und Leistungsmotivation [Theories of learning and achievement motivation]. In L. Ahnert Theorien in der Entwicklungspsychologie Theories in Developmental. Psychology. Berlin, Heidelberg: Springer, 252-281 (2014)

23. J. A. Moriano, F. Molero, G. Topa, J.-P. Lévy Mangin, The influence of transformational leadership and organizational identification on intrapreneurship. International Entrepreneurship and Management Journal. 10(1), 103-119 (2014)

24. C. Müller, Entrepreneurship und Leadership - Erfolgsfaktoren am Beispiel eines Familienunternehmens. In: M. Raich, H. Pechlaner, H. H. Hinterhuber, Entrepreneurial Leadership. Wiesbaden: Deutscher Univesitäts-Verlag, 117-130 (2007)

25. J. Heckhausen, H. Heckhausen, Motivation und Handeln [Motivation and Action]. Berlin, Heidelberg: Springer (2010) 
26. S. G. Walter, A. Walter, Deutsche Universitäten als Gründungsinkubatoren: Der Beitrag der Gründungsausbildung zur Gründungsintention von Studierenden [German universities as start-up incubators: The contribution of start-up training to the start-up intention of students]. Schmalenbach Journal of Business Research. 60(6), 542-569 (2008)

27. S. Weber, M. Wiethe-Körprich, S. Bley, C. Weiß, F. Achtenhagen, Intrapreneurship-Verhalten an kaufmännischen Arbeitsplätzen [Intrapreneurship behavior in commercial workplaces]. Empirische Pädagogik. 29(1), 84-105 (2015)

28. N. Nicholson, J. Arnold, From Expectations to experience: Graduates entering large corporations. Journal of Organizational Behavior. 12(5), 413-429 (1991)

29. X. Justus, J. F. Faltermeier, S. P. Saßmannshausen, Denken und Handeln grenzüberschreitend fördern [Promote thinking and acting across borders]. In: Forschung 2018 [online]. Available at: https://www.othregensburg.de/fileadmin/media/forschung/Dateien_2018/Forschungsbericht-2018.pdf (2018)

30. A. Renkl, Drei Dogmen guten Lernens und Lehrens: Warum sie falsch sind [Three Dogmas of Good Learning and Teaching: Why They Are Wrong]. Psychologische Rundschau. 66(4), 211-220 (2015)

31. K. Wilson, Entrepreneurship Education in Europe. In J. Potter, Entrepreneurship and Higher Education. Paris: OECD, 119-138 (2008) 